\title{
Analysis of aquifers, humidity levels with geoelectric resistivity value, and NDW Index in the geothermal area of North Langowan
}

\author{
Indonesian title: \\ Analisis akuifer, tingkat kelembaban dengan nilai resistivitas geolistrik, dan Index NDW di daerah \\ panas bumi Langowan Utara \\ Bella M. Wowor ${ }^{1 *}$, Fabian J. Manoppo ${ }^{2}$, Herawaty Riogilang ${ }^{2}$ \\ ${ }^{1}$ Program Studi Magister Teknik Sipil, Pascasarjana, Universitas Sam Ratulangi, Jl. Kampus Unsrat Bahu, Manado \\ ${ }^{2}$ Fakultas Teknik, Universitas Sam Ratulangi, Jl. Kampus Unsrat Bahu, Manado \\ *Corresponding author: bellamonicawowor@gmail.com
}

Received: 3 August 2021 -Revised: 3 September 2021 - Accepted: 3 September 2021

\begin{abstract}
This research was conducted to examine the condition (location, depth, and thickness) of the aquifer, to assess the humidity level using the NDW index, and to determine the relationship between aquifer conditions and the sustainability of the geothermal system using the geoelectrical method of resistivity in the North Langowan geothermal area. The comparison between rock layer resistivity data and spectral values based on geologicalhydrogeological maps was carried out to determine the relationship between aquifer conditions and humidity levels in the geothermal area to the continuity of the geothermal system in the Tompaso region. The data was processed using IP2WIN and ILWIS programs. The results showed that at the research site there were semi-confined aquifers and free aquifers, which were indicated by low resistivity values. It can be concluded that the aquifer in the North Langowan geothermal area was at a depth ranging from $0 \mathrm{~m}$ to $16 \mathrm{~m}$ with a thickness ranging from 3.98 to $12 \mathrm{~m}$, moderate wetness, and has a good relationship in supporting the continuity of the Tompaso geothermal system.
\end{abstract}

Keywords: geothermal; aquifer; geoelectrical resistivity; NDW index; North Langowan

\section{PENDAHULUAN}

Energi panas bumi (hydrothermal) adalah energi yang berasal dari dalam bumi yang berupa air panas atau uap yang terbentuk dalam reservoir di dalam bumi melalui pemanasan air bawah permukaan oleh batuan beku panas. Sumber energi panas bumi terbagi dalam empat kategori yaitu uap kering, air panas, batu kering, panas, dan sumber bertekanan tinggi (Tillery, 2007).

Pemanfaatan energi panas bumi dapat digunakan sebagai pembangkit listrik tenaga uap. Energi ini baik dalam pemanfaatannya, karena dapat dihasilkan secara terus-menerus dan berkelanjutan.

Pada umumnya, sistem panas bumi terdiri dari beberapa komponen, seperti sumber panas, reservoir, batuan penudung, daerah resapan, dan daerah luahan (Sardiyanto, 2010). Daerah resapan (recharge), sebagai daerah di mana arah aliran air tanah di tempat tersebut bergerak menjauhi muka tanah, sangat memiliki peranan penting bagi terbentuknya reservoir panas bumi. Air tanah terkumpul pada lapisan yang disebut dengan akuifer.

Meskipun air tanah tidak dapat secara langsung diamati melalui permukaan bumi, namun penyelidikan bawah permukaan merupakan awal penyelidikan yang cukup penting, paling tidak dapat memberikan suatu gambaran mengenai lokasi keberadaan air tanah tersebut. Menurut Fauziyah (2015), untuk menggambarkan struktur bawah permukaan dapat digunakan metode geofisika, yaitu metode geolistrik tahanan jenis (resistivity). Metode ini menggunakan nilai resistivitas untuk mengeksplorasi alam seperti sistem hidrotermal, karena metode ini memiliki sensitivitas yang besar untuk mengetahui adanya fluida dan hidrotermal.

Metode geolistrik tahanan jenis (resistivity) dan pengindraan jauh Index NDW digunakan untuk menganalisis kondisi akuifer serta tingkat kelembaban daerah panas bumi. Program IP2WIN digunakan 


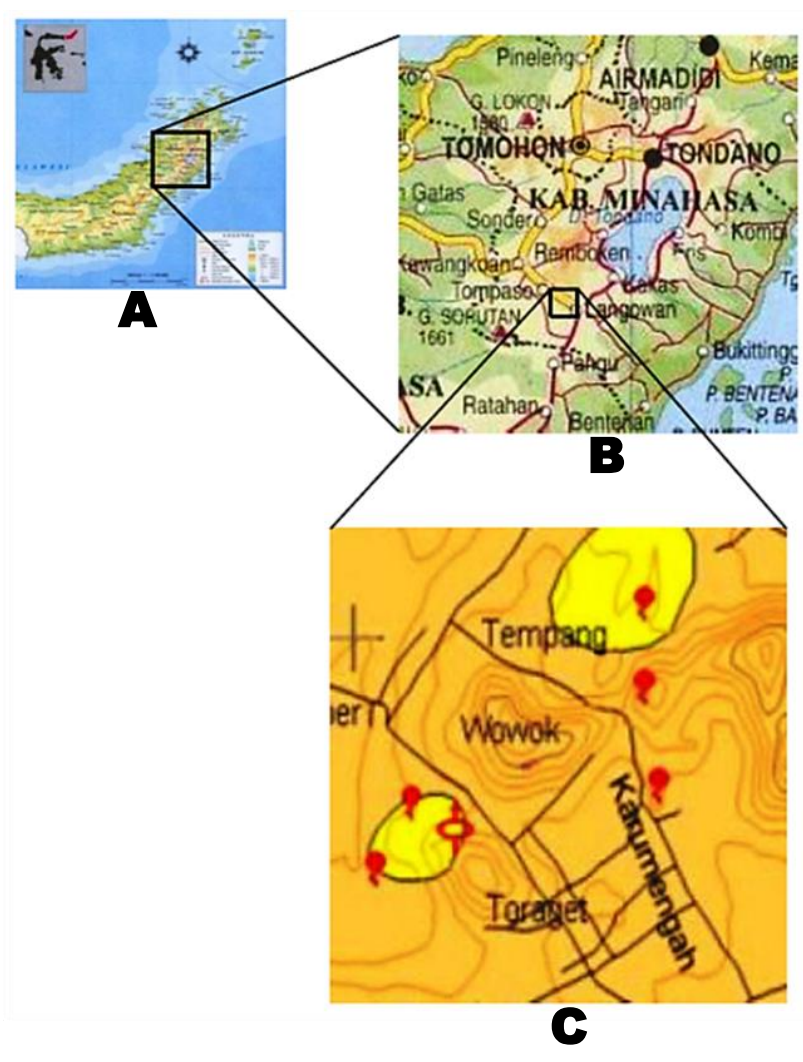

Gambar 1. Peta daerah penelitian

(A: Provinsi Sulawesi Utara; B: Kabupaten Minahasa; C: Desa Tempang Dua \& Desa Karumenga)

untuk interpretasi data geolistrik dan di dukung dengan data geologi serta hidrogeologi daerah sekitar sehingga di ketahui letak, kedalaman, dan ketebalan akuifer serta kondisi bawah lapisan dan keberadaan akuifer daerah penelitian. Pengambilan data geolistrik melalui 4 lintasan. Program ILWIS digunakan untuk mengetahui nilai spektral manifestasi dengan hasil berupa peta Index NDW sehingga dapat di ketahui tingkat kelembaban daerah penelitian lewat objek manifestasi panas bumi.

Di Indonesia, khususnya Sulawesi Utara, memiliki potensi besar untuk kegiatan industri Pembangkit Listrik Tenaga Panas Bumi (PLTP) di mana kegiatan eksplorasinnya menyangkut penggunaan air tanah. Kecamatan Langowan Utara, Kabupaten Minahasa, merupakan bagian dari lapangan panas bumi hidrotermal area Tompaso, Sulawesi Utara, yang tandai dengan adanya manifestasi di sekitar daerah tersebut, dan ini merupakan bagian dari pangan panas bumi. Kajian geofisika yang dilakukan oleh Handoko (2010), mengindikasikan adanya sumber daya panas bumi bawah permukaan yang di tandai oleh manfestasi panas bumi. Oleh karena itu untuk menunjang eksplorasi dan upaya konservasi energi panas bumi dibutuhkan analisis kondisi akuifer dan tingkat kelembaban tanah pada daerah sekitar manifestasi panas bumi, khususnya yang ada di Desa Tempang
Dua dan Desa Karumenga, serta hubungannya terhadap sistem panas bumi di area Tompaso didukung oleh data pada peta geologi dan peta hidrogeologi daerah penelitian.

Penelitian ini bertujuan untuk menganalisis kondisi akuifer, meliputi letak, kedalaman, dan ketebalannya, yang terdapat di daerah sekitar manifestasi panas bumi di Kecamatan Langowan Utara; menentukan nilai index air manifestasi panas bumi pada citra landsat di Kecamatan Langowan Utara; dan mengetahui hubungan kondisi akuifer dan tingkat kelembaban daerah penelitian terhadap kelangsungan sistem panas bumi area Tompaso.

\section{MATERIAL DAN METODE}

\section{Lokasi, Waktu, Desain, dan Variabel Penelitian}

Secara administratif, lokasi penelitian berada di Desa Tempang Dua dan Desa Karumenga, Kecamatan Langowan Utara, Kabupaten Minahasa, Provinsi Sulawesi Utara (Gambar 1). Penelitian dilakukan pada bulan Agustus 2017. Kondisi cuaca pada saat pengukuran geolistrik tahanan jenis adalah cerah dan cerah berawan. Daerah penelitian berada pada ketinggian rata-rata $754 \mathrm{mdpl}$ dengan topografi landai dan memiliki sebaran manifestasi panas bumi (discharge area) berupa kolam air panas, matai air panas dan kolam lumpur.

Tabel 1 menampilkan alat dan bahan yang dibutuhkan dalam penelitian. Desain penelitian dibagi dalam tiga tahapan, yaitu persiapan, pelaksanaan, dan penyelesaian (Gambar 2). Variabel pada penelitian, yaitu kondisi akuifer dan tingkat kelembaban.

\section{Teknik Pengumpulan Data}

Kondisi akuifer dapat diketahui melalui nilai resistivitas $(\rho)$ yang diperoleh. Nilai resistivitas atau resistivity merupakan nilai tahanan jenis suatu bahan yang ada di dalam bumi. Resistivitas ( $\rho$ ) diperoleh berdasarkan parameter hasil perhitungan yaitu resistansi (R) dan faktor geometri (K). Parameter hasil perhitungan ini berasal dari parameter hasil pengukuran yaitu beda potensial $(\Delta \mathrm{V})$, kuat arus $(I)$, jarak antara stasiun dengan elektroda potensial $(M N / 2)$, dan jarak antara stasiun dengan elektroda arus $(A B / 2)$.

Untuk tingkat kelembaban dapat di ketahui melalui analisis index air atau dikenal sebagai nilai Normalize Difference Water Index (NDWI), yang dikembangkan oleh Gao (1996). Nilai indeks air di peroleh dari band Near Infrared (NIR) dan band SWIR. Nilai NDWI ini dikembangkan untuk meng- 
Wowor et al.: Analysis of aquifers, humidity levels with geoelectric resistivity, and NDW Index ...

Tabel 1

Jenis, nama, dan spesifikasi alat yang digunakan dalam pengumpulan data

\begin{tabular}{ll}
\hline Jenis Alat & Nama/Spesifikasi \\
\hline Resistivitymeter & OYO Model 2115 McOHM \\
Kabel elektroda arus & 2 gulung; panjang \pm 1000 meter \\
Kabel elektroda potensial & 2 gulung; panjang \pm 60 meter \\
Elektroda & 4 buah \\
Palu & \\
Aki & Tegangan 12V; kapasitas 32Ah; Merek Incoe Gold NS40 \\
GPS (Global Positioning System) & Garmin eTrex Vista HCx. \\
Kompas Geologi & Brunton 5008, oleh Brunton, Inc. Riverton, Wyoming \\
Kamera & Digital \\
Meteran & \\
Alat tulis menulis & Clipboard; pena \\
Peta geologi & Peta Geologi lembar Manado, Sulawesi Utara oleh A.C. Effendi dan S.S. \\
& Bawono (1997) edisi ke-2 \\
Peta hidrologi & Peta Hidrogeologi Indonesia lembar 2416 Kotabunan dan 2417 Manado \\
& (Sulawesi) oleh Sukrisno (1994) \\
Data citra satelit & Landsat 8 OLI TIRS Tahun 2021 bulan Januari \\
& Microsoft Excel \\
Perangkat lunak (software) & IPI2Win - IPI to win Version 3.1.2c \\
& ILWIS \\
\hline
\end{tabular}

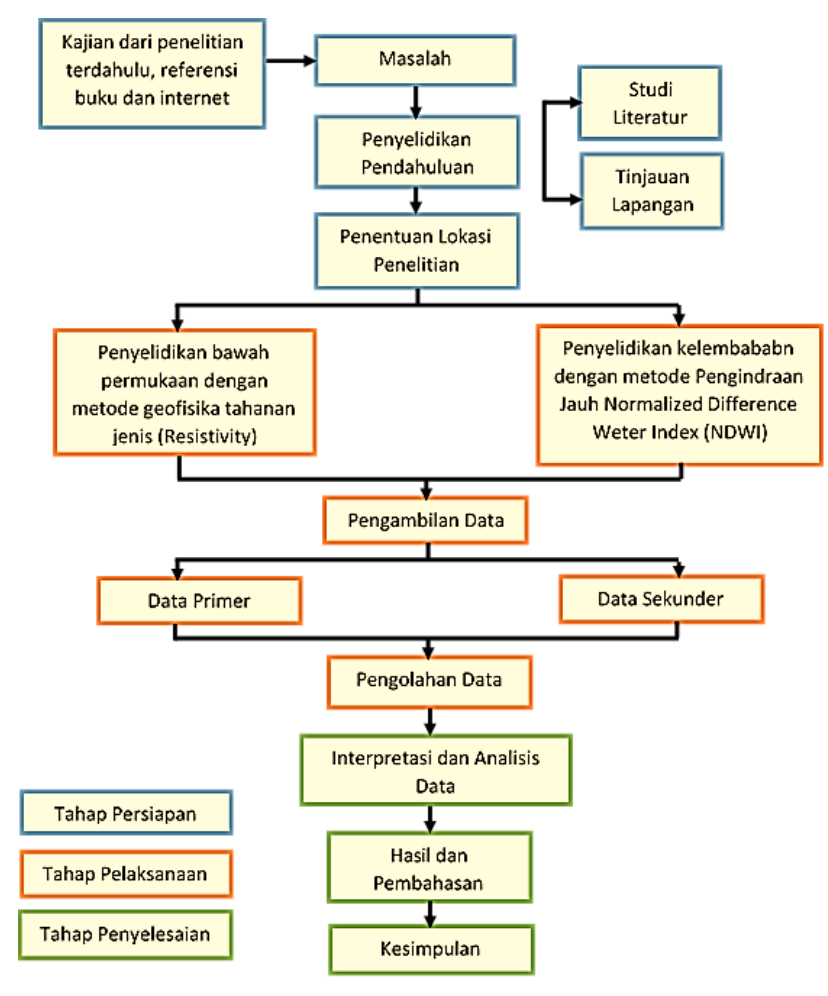

Gambar 2. Diagram blok desain penelitian

gambarkan badan air dari citra satelit; dihitung menggunakan rumus:

NDWI $=($ Band5 - Band 6$) /($ Band5 + Band6 $)$ atau NDWI = NIR - SWIR / NIR + SWIR

Nilai NDWI terletak antara -1 dan 1 . Umumnya, nilai NDWI badan air lebih besar dari 0,5 . Vegetasi memiliki nilai yang jauh lebih kecil yang
Tabel 2. Klasifikasi nilai NDWI

\begin{tabular}{ccc}
\hline Kelas & Nilai NDWI & Tingkat Kebasahan \\
\hline 1 & $-1<$ NDWI $<0$ & Non Badan Air \\
2 & $0<$ NDWI $<0.33$ & Kebasahan Sedang \\
3 & $0.33<$ NDWI $<1$ & Kebasahan Tinggi \\
\hline
\end{tabular}

membedakan vegetasi dari badan air dengan mudah. Klasifikasi Nilai NDWI dapat di lihat pada Tabel 2.

\section{Teknik Pengolahan dan Analisis Data}

Pengolahan dan analisis data, berturut-turut, ditampilkan pada Gambar 3 dan 4.

\section{HASIL DAN PEMBAHASAN}

\section{Kondisi Akuifer}

Ditinjau dari Peta Geologi Indonesia lembar Manado, sebaran batuan pada lokasi penelitian adalah batuan gunung api dengan usia tersier pliosen, yaitu Tufa Tondano (QTv), yang merupakan klastika kasar gunung api, berkomposisi andesit, tersusun dari komponen menyudut hingga menyudut tanggung, tercirikan oleh banyak pecahan batu apung, batu apung lapili, breksi, ignimbrit sangat padat, berstruktur aliran. Satuan ini terdapat di sekitar Danau Tondano, di bagian Utara daerah Minahasa, membentuk punggungan yang menggelombang rendah. Aliran lava berkomposisi andesit trakhit. Tuff bersifat trakhit yang sangat lapuk, berwarna putih hingga kelabu kekuningan. Endapan piroklastika ini diperkirakan berasal dari dan terjadi 


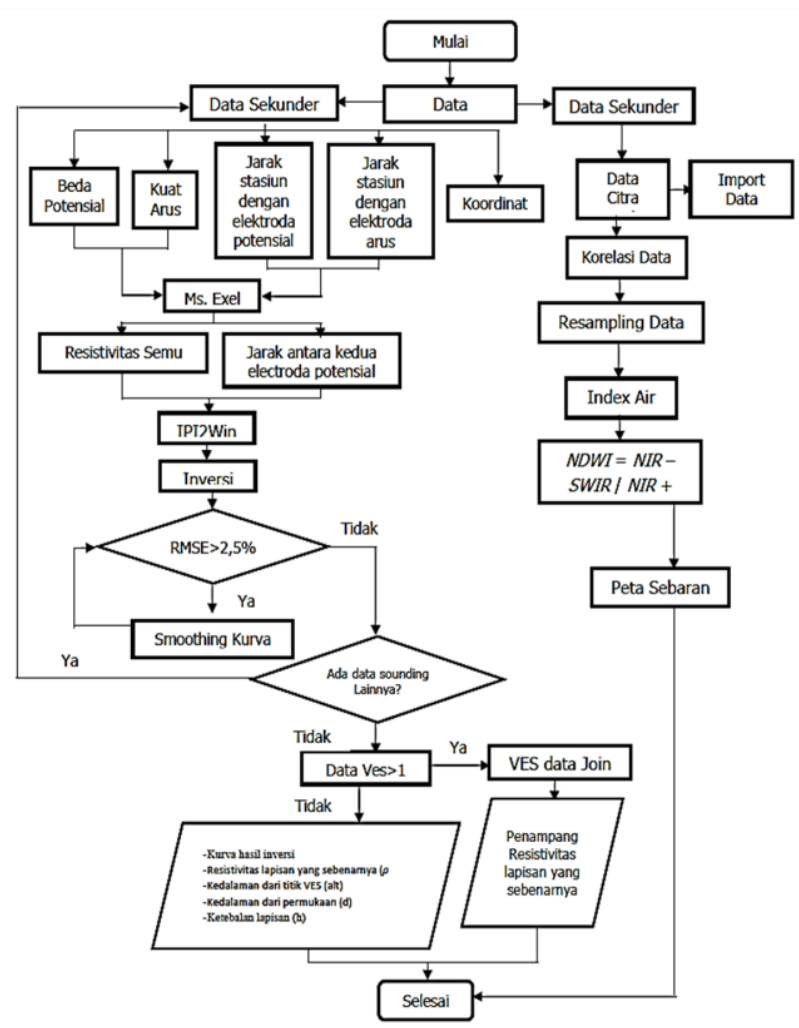

Gambar 3. Diagram alir pengolahan data

sebagai hasil letusan hebat pada waktu pembentukan Kaldera Tondano.

Ditinjau dari Peta Hidrogeologi Indonesia lembar 2416 Kotabunan dan 2417 Manado, komposisi litologi batuan dan kelulusannya pada lokasi penelitian merupakan batuan gunung api tua, terdiri dari tufa, tufa lapili, breksi, pecahan batuapung, dan aliran lava; umumnya bersifat andesitan sampai basalan. Sebagian dari breksi mengandung sisipan tufa, batu pasir, batu lempung dan lensa batu gamping; umumnya kelulusan rendah. Peta menunjukkan, arah aliran air tanah berasal dari Gunung Soputan dan Gunung Bindengan yang kemudian menuju ke daerah penelitian.

Tabel 3-6 menampilkan hasil pengukuran dan perhitungan geolistrik tahanan jenis. Nilai konstanta geometri Schlumberger (Ks) ditunjukkan oleh kolom berwarna hijau. Pengukuran untuk line 1 dimulai pada panjang $\mathrm{AB} / 2=1,5 \mathrm{~m}$ dan $\mathrm{MN} / 2=0,5 \mathrm{~m}$ sampai pada panjang $\mathrm{AB} / 2=150 \mathrm{~m}$ dan $\mathrm{MN} / 2=25$ $\mathrm{m}$ dengan 24 titik sounding (Tabel 3). Pengukuran untuk line 2 dimulai pada panjang $\mathrm{AB} / 2=1,5 \mathrm{~m}$ dan $\mathrm{MN} / 2=0,5 \mathrm{~m}$ sampai panjang $\mathrm{AB} / 2=100 \mathrm{~m}$ dan $\mathrm{MN} / 2=25 \mathrm{~m}$ dengan 22 titik sounding (Tabel 4). Pengukuran untuk line 3 dan line 4 dimulai pada panjang $\mathrm{AB} / 2=1,5 \mathrm{~m}$ dan $\mathrm{MN} / 2=0,5 \mathrm{~m}$ sampai panjang $\mathrm{AB} / 2=75 \mathrm{~m}$ dan $\mathrm{MN} / 2=10 \mathrm{~m}$ dengan 20 titik sounding (Tabel 5 dan 6).

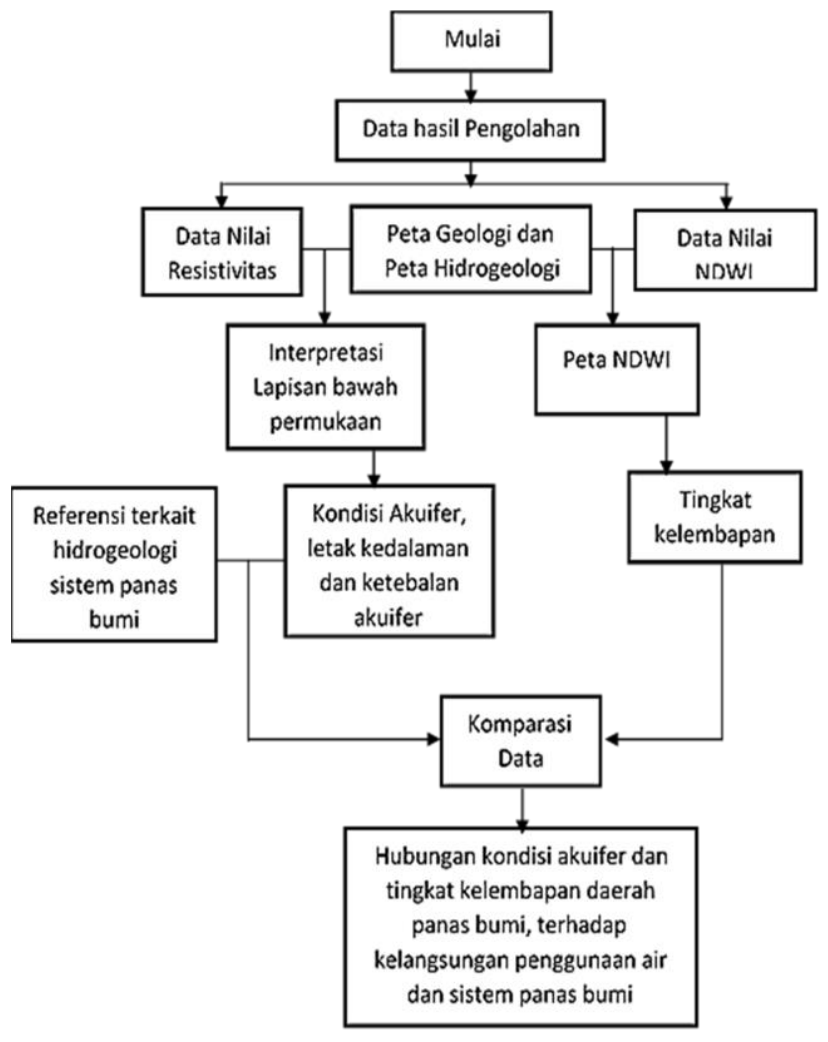

Gambar 4. Diagram blok analisis data

Inversi terhadap nilai tahanan jenis semu dilakukan untuk memperoleh nilai tahanan jenis yang sebenarnya sesuai dengan diagram alir teknik pengolahan data pada Gambar 3. Hasil inversi untuk line 1 dapat dilihat pada Gambar 5, 6, dan Tabel 7. Kurva pada Gambar 5 memiliki Root Mean Square Error (RMSE) sebesar 2,15\%.

Hasil inversi untuk line 2 dapat dilihat pada Gambar 7, Gambar 6, dan Tabel 8. Kurva pada Gambar 7 memiliki RMSE sebesar 2,11\%.

Data untuk kedalaman, ketebalan, dan resistivitas lapisan untuk line 1 dan line 2 dapat dilihat pada Tabel 7 dan 8. Interpretasi jenis lapisan berdasarkan Tabel 7 dapat dijelaskan sebagai berikut:

- Tanah penutup: kedalaman sampai dengan 2,34 $\mathrm{m}$, mempunyai resistivitas 51,5-135 $\Omega \mathrm{m}$, diinterpretasikan sebagai lapisan tufa pasiran.

- Lapisan kedua: kedalaman 2,34-43,8 m mempunyai resistivitas 6,31-16,9 $\Omega \mathrm{m}$, diinterpretasikan sebagai lempung.

- Lapisan ketiga: kedalaman 43,8 m sampai tak terdeteksi, mempunyai resistivitas $0,0521-0,598$ $\Omega \mathrm{m}$, diinterpretasikan sebagai lapisan air tanah.

Interpretasi jenis lapisan berdasarkan Tabel 8 , dapat dijelaskan sebagai berikut: 
Wowor et al.: Analysis of aquifers, humidity levels with geoelectric resistivity, and NDW Index ...

Tabel 3

Data geolistrik tahanan jenis line 1

\begin{tabular}{|c|c|c|c|c|c|c|c|c|}
\hline \multirow{2}{*}{\multicolumn{2}{|c|}{\begin{tabular}{|l|} 
Lokasi \\
No. Lokasi \\
\end{tabular}}} & \multicolumn{7}{|c|}{ : Desa Tempang Dua } \\
\hline & & \multicolumn{7}{|l|}{ :TM 01} \\
\hline & \multicolumn{7}{|c|}{$\mathrm{N} 305^{\circ} \mathrm{E}$} \\
\hline \multicolumn{2}{|l|}{ Elevasi } & \multicolumn{7}{|l|}{ : $751 \mathrm{~m}$} \\
\hline \multicolumn{2}{|l|}{ Koordinat } & \multicolumn{7}{|c|}{0703603 East, 0129742 North (Zona: $51 \mathrm{~N}$ ) } \\
\hline \multicolumn{2}{|l|}{ Cuaca } & \multicolumn{7}{|c|}{ :Cerah Berawan } \\
\hline$A B / 2 \quad M N / 2$ & 0.5 & 5 & 10 & 25 & $\mathrm{~V}(\mathrm{mV})$ & $I(m A)$ & $R(\Omega)$ & $\rho_{a}(\Omega \mathrm{m})$ \\
\hline 1.5 & 6.28 & & & & 151.2 & 9.993 & 15.13059 & 95.068 \\
\hline 2 & 11.8 & & & & 65.66 & 9.994 & \begin{tabular}{|l|l|}
6.569942 \\
\end{tabular} & 77.400 \\
\hline 2.5 & 18.8 & & & & 32.53 & 9.993 & 3.255279 & 61.361 \\
\hline 3 & 27.5 & & & & 18.52 & 9.994 & 1.853112 & 50.940 \\
\hline 4 & 49.5 & & & & 7.76 & 9.993 & 0.776544 & 38.423 \\
\hline 5 & 77.8 & & & & 3.713 & 9.994 & 0.371523 & 28.888 \\
\hline 6 & 112.31 & & & & 1.876 & 9.993 & 0.187731 & 21.084 \\
\hline 8 & 200.28 & & & & 0.813 & 9.992 & 0.081365 & 16.296 \\
\hline 10 & 313.37 & & & & 0.408 & 9.992 & 0.040833 & 12.796 \\
\hline 12 & 451.6 & & & & 0.257 & 9.992 & 0.025721 & 11.616 \\
\hline 15 & 706.07 & & & & 0.15 & 9.992 & 0.015012 & 10.600 \\
\hline 15 & & 62.8 & & & 1.853 & 9.99 & 0.185485 & 11.654 \\
\hline 20 & & 117.8 & & & 0.837 & 9.907 & 0.084486 & 9.953 \\
\hline 25 & & 188.5 & & & 0.523 & 9.99 & 0.052352 & 9.868 \\
\hline 30 & & 274.9 & & & 0.34 & 9.992 & 0.034027 & 9.354 \\
\hline 30 & & & 125.7 & & 0.853 & 9.99 & 0.085385 & 10.730 \\
\hline 40 & & & 235.6 & & 0.377 & 9.99 & 0.037738 & 8.892 \\
\hline 50 & & & 377.0 & & 0.225 & 9.99 & 0.022523 & 8.491 \\
\hline 60 & & & 549.8 & & 0.132 & 9.99 & 0.013213 & 7.264 \\
\hline 75 & & & 867.9 & & 0.077 & 9.992 & 0.007706 & 6.688 \\
\hline 75 & & & & 314.16 & 0.39 & 9.99 & 0.039039 & 12.264 \\
\hline 100 & & & & 589 & 0.117 & 9.99 & 0.011712 & 6.899 \\
\hline 125 & & & & 942.5 & 0.025 & 9.99 & 0.002503 & 2.359 \\
\hline 150 & & & & 1374 & 0.034 & 9.99 & 0.003403 & 4.678 \\
\hline
\end{tabular}

Tabel 5

Data geolistrik tahanan jenis line 3

\begin{tabular}{|l|l|}
\hline Lokasi & $:$ Desa Karumenga \\
\hline No. Lokasi & $:$ KR 02 \\
\hline Arah & $: \mathrm{N} 179^{\circ} \mathrm{E}$ \\
\hline Elevasi & $: 762 \mathrm{~m}$ \\
\hline Koordinat & $: 0703921$ East, 0129511 North (Zona: $51 \mathrm{~N}$ ) \\
\hline Cuaca & $:$ Cerah \\
\hline
\end{tabular}

\begin{tabular}{|c|c|c|r|r|r|r|r|}
\hline $\mathbf{A B} / \mathbf{2}$ & $\mathbf{0 . 5}$ & $\mathbf{5}$ & $\mathbf{1 0}$ & $\mathbf{V}(\mathbf{m V})$ & $\mathrm{I}(\mathbf{m A})$ & $\mathbf{R}(\Omega)$ & $\rho_{a(\Omega \mathrm{m})}$ \\
\hline $\mathbf{1 . 5}$ & $\mathbf{6 . 2 8}$ & & & 291 & 4.997 & 58.23494 & 365.901 \\
\hline $\mathbf{2}$ & 11.8 & & & 245.2 & 9.996 & 24.52981 & 288.985 \\
\hline $\mathbf{2 . 5}$ & 18.8 & & & 134.6 & 9.993 & 13.46943 & 253.893 \\
\hline $\mathbf{3}$ & $\mathbf{2 7 . 5}$ & & & 84.32 & 9.993 & 8.437907 & 231.949 \\
\hline $\mathbf{4}$ & 49.5 & & & 40.96 & 9.992 & 4.099279 & 202.833 \\
\hline $\mathbf{5}$ & $\mathbf{7 7 . 8}$ & & & 21.3 & 9.993 & 2.131492 & 165.733 \\
\hline $\mathbf{6}$ & 112.31 & & & 9.983 & 9.99 & 0.999299 & 112.233 \\
\hline $\mathbf{8}$ & 200.28 & & & 7.333 & 9.992 & 0.733887 & 146.980 \\
\hline $\mathbf{1 0}$ & 313.37 & & & 3.103 & 9.99 & 0.310611 & 97.337 \\
\hline $\mathbf{1 2}$ & $\mathbf{4 5 1 . 6}$ & & & 2.706 & 9.99 & 0.270871 & 122.326 \\
\hline $\mathbf{1 5}$ & $\mathbf{7 0 6 . 0 7}$ & & & 0.43 & 9.99 & 0.043043 & 30.392 \\
\hline $\mathbf{1 5}$ & & 62.8 & & 13.57 & 9.992 & 1.358086 & 85.331 \\
\hline $\mathbf{2 0}$ & & 117.8 & & 8.004 & 9.99 & 0.801201 & 94.389 \\
\hline $\mathbf{2 5}$ & & 188.5 & & 5.052 & 9.99 & 0.505706 & 95.323 \\
\hline $\mathbf{3 0}$ & & 274.9 & & 3.432 & 9.99 & 0.343544 & 94.436 \\
\hline $\mathbf{3 0}$ & & & 125.7 & 7.714 & 9.99 & 0.772172 & 97.034 \\
\hline $\mathbf{4 0}$ & & & 235.6 & 3.988 & 9.992 & 0.399119 & 94.040 \\
\hline $\mathbf{5 0}$ & & & 377.0 & 2.276 & 9.99 & 0.227828 & 85.889 \\
\hline $\mathbf{6 0}$ & & & 549.8 & 0.746 & 9.99 & 0.074675 & 41.055 \\
\hline $\mathbf{7 5}$ & & & 867.9 & 0.303 & 9.99 & 0.03033 & 26.323 \\
\hline
\end{tabular}

- Tanah penutup: kedalaman sampai dengan 3,98 m, mempunyai resistivitas 12,1-28,5 $\Omega \mathrm{m}$, diinterpretasikan sebagai lapisan lanau.

- Lapisan kedua: kedalaman 3,98-8,41 m, mempunyai resistivitas $3,53 \Omega \mathrm{m}$, diinterpretasikan sebagai lempung pasiran.
Tabel 4

Data geolistrik tahanan jenis line 2

\begin{tabular}{|c|c|c|c|c|c|c|c|c|}
\hline \multirow{2}{*}{\multicolumn{2}{|c|}{\begin{tabular}{|l|} 
Lokasi \\
No. Lokasi \\
\end{tabular}}} & \multicolumn{7}{|c|}{ : Desa Tempang Dua } \\
\hline & & \multicolumn{7}{|l|}{ :TM 01} \\
\hline \multicolumn{2}{|l|}{ Arah } & \multicolumn{7}{|c|}{$: \mathrm{N} 305^{\circ} \mathrm{E}$} \\
\hline \multicolumn{2}{|l|}{ Elevasi } & \multicolumn{7}{|l|}{$751 \mathrm{~m}$} \\
\hline \multicolumn{2}{|l|}{ Koordinat } & \multicolumn{7}{|c|}{ : 0703603 East, 0129742 North (Zona: $51 \mathrm{~N}$ ) } \\
\hline \multicolumn{2}{|l|}{ Cuaca } & \multicolumn{7}{|c|}{ :Cerah Berawan } \\
\hline$A B / 2 M N / 2$ & 0.5 & 5 & 10 & 25 & $\mathrm{~V}(\mathrm{mV})$ & I (mA) & $R(\Omega)$ & $\rho_{a}(\Omega \mathrm{m})$ \\
\hline 1.5 & 6.28 & & & & 151.2 & 9.993 & 15.13059 & 95.068 \\
\hline 2 & 11.8 & & & & 65.66 & 9.994 & 6.569942 & 77.400 \\
\hline 2.5 & 18.8 & & & & 32.53 & 9.993 & 3.255279 & 61.361 \\
\hline 3 & 27.5 & & & & 18.52 & 9.994 & 1.853112 & 50.940 \\
\hline 4 & 49.5 & & & & 7.76 & 9.993 & 0.776544 & 38.423 \\
\hline 5 & 77.8 & & & & 3.713 & 9.994 & 0.371523 & 28.888 \\
\hline 6 & 112.31 & & & & 1.876 & 9.993 & 0.187731 & 21.084 \\
\hline 8 & 200.28 & & & & 0.813 & 9.992 & 0.081365 & 16.296 \\
\hline 10 & 313.37 & & & & 0.408 & 9.992 & 0.040833 & 12.796 \\
\hline 12 & 451.6 & & & & 0.257 & 9.992 & 0.025721 & 11.616 \\
\hline 15 & 706.07 & & & & 0.15 & 9.992 & 0.015012 & 10.600 \\
\hline 15 & & 62.8 & & & 1.853 & 9.99 & 0.185485 & 11.654 \\
\hline 20 & & 117.8 & & & \begin{tabular}{|l|l|}
0.837 \\
\end{tabular} & 9.907 & 0.084486 & 9.953 \\
\hline 25 & & 188.5 & & & 0.523 & 9.99 & 0.052352 & 9.868 \\
\hline 30 & & 274.9 & & & 0.34 & 9.992 & 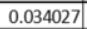 & 9.354 \\
\hline 30 & & & 125.7 & & 0.853 & 9.99 & 0.085385 & 10.730 \\
\hline 40 & & & 235.6 & & 0.377 & 9.99 & 0.037738 & 8.892 \\
\hline 50 & & & 377.0 & & 0.225 & 9.99 & 0.022523 & 8.491 \\
\hline 60 & & & 549.8 & & 0.132 & 9.99 & 0.013213 & 7.264 \\
\hline 75 & & & 867.9 & & \begin{tabular}{|l|l|}
0.077 \\
\end{tabular} & 9.992 & 0.007706 & 6.688 \\
\hline 75 & & & & 314.16 & 0.39 & 9.99 & 0.039039 & 12.264 \\
\hline 100 & & & & 589 & 0.117 & 9.99 & 0.011712 & 6.899 \\
\hline 125 & & & & 942.5 & 0.025 & 9.99 & 0.002503 & 2.359 \\
\hline 150 & & & & 1374 & 0.034 & 9.99 & 0.003403 & 4.678 \\
\hline
\end{tabular}

Tabel 6

Data geolistrik tahanan jenis line 4

\begin{tabular}{|l|l|}
\hline Lokasi & : Desa Karumenga \\
\hline No. Lokasi & $:$ KR 01 \\
\hline Arah & $: \mathrm{N} 355^{\circ} \mathrm{E}$ \\
\hline Elevasi & $: 753 \mathrm{~m}$ \\
\hline Koordinat & $: 0703956$ East, 0129332 North (Zona: $51 \mathrm{~N}$ ) \\
\hline Cuaca & $:$ Cerah \\
\hline
\end{tabular}

\begin{tabular}{|c|c|c|c|c|c|c|c|}
\hline$A B / 2{ }^{M N / 2}$ & 0.5 & 5 & 10 & $\mathrm{~V}(\mathrm{mV})$ & $I(m A)$ & $R(\Omega)$ & $\rho_{a}(\Omega \mathrm{m})$ \\
\hline 1.5 & 6.28 & & & 78 & 9.993 & 7.805464 & 49.043 \\
\hline 2 & 11.8 & & & 30.13 & 9.996 & 3.014206 & 35.510 \\
\hline 2.5 & 18.8 & & & 15.09 & 9.993 & 1.510057 & 28.464 \\
\hline 3 & 27.5 & & & 8.611 & 9.993 & 0.861703 & 23.687 \\
\hline 4 & 49.5 & & & 3.757 & 9.99 & 0.376076 & 18.608 \\
\hline 5 & 77.8 & & & 2.035 & 9.992 & 0.203663 & 15.836 \\
\hline 6 & 112.31 & & & 1.248 & 9.99 & 0.124925 & 14.031 \\
\hline 8 & 200.28 & & & 0.603 & 9.993 & 0.060342 & 12.085 \\
\hline 10 & 313.37 & & & 0.344 & 9.99 & 0.034434 & 10.791 \\
\hline 12 & 451.6 & & & 0.266 & 9.987 & 0.026635 & 12.028 \\
\hline 15 & 706.07 & & & 0.143 & 9.987 & 0.014319 & 10.110 \\
\hline 15 & & 62.8 & & 1.1923 & 9.987 & 0.119385 & 7.501 \\
\hline 20 & & 117.8 & & 0.89 & 9.987 & 0.089116 & 10.499 \\
\hline 25 & & 188.5 & & 0.4 & 8.987 & 0.044509 & 8.390 \\
\hline 30 & & 274.9 & & 0.229 & 9.987 & 0.02293 & 6.303 \\
\hline 30 & & & 125.7 & 1.82 & 9.988 & 0.182219 & 22.898 \\
\hline 40 & & & 235.6 & 0.282 & 9.987 & 0.028237 & 6.653 \\
\hline 50 & & & 377.0 & 0.147 & 9.987 & 0.014719 & 5.549 \\
\hline 60 & & & 549.8 & 0.051 & 9.987 & 0.005107 & 2.808 \\
\hline 75 & & & 867.9 & 0.047 & 9.988 & 0.004706 & 4.084 \\
\hline
\end{tabular}

- Lapisan ketiga: kedalaman 8,41-17,9 m, mempunyai resistivitas 49,2 $\Omega \mathrm{m}$, diinterpretasikan sebagai lapisan pasir tufaan.

- Lapisan keempat: kedalaman 17,9 m sampai tak terdeteksi, mempunyai resistivitas 0,0632-0,283 $\Omega \mathrm{m}$, diinterpretasikan sebagai lapisan air tanah. 

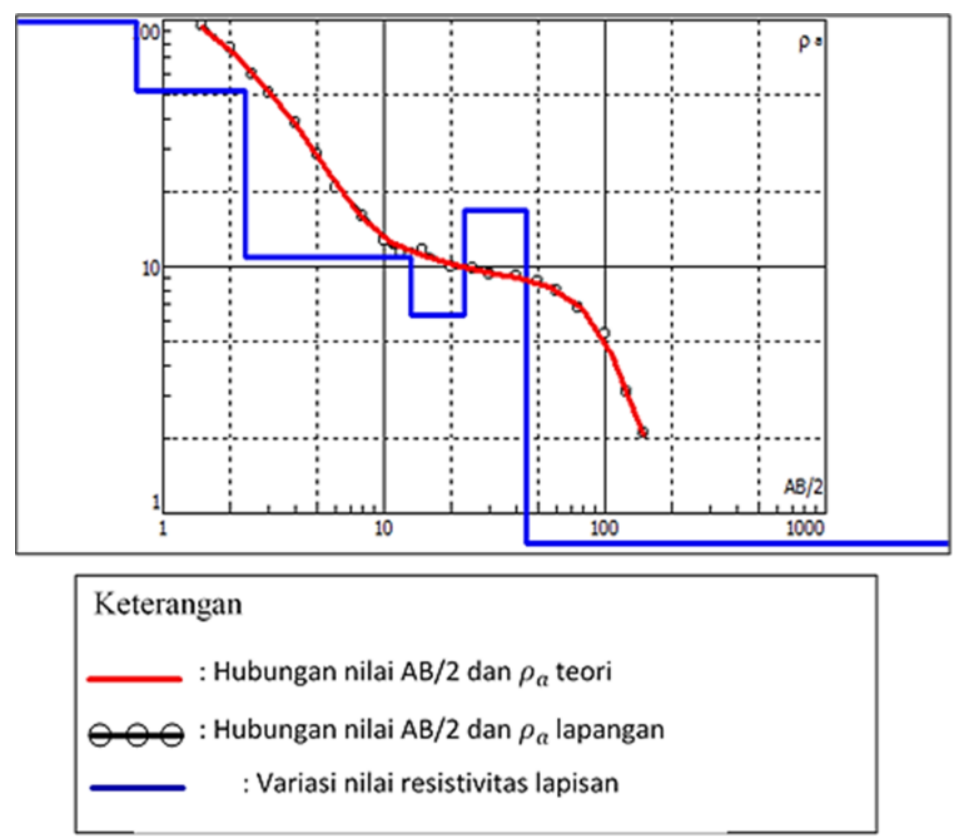

Gambar 5. Kurva hasil inversi untuk line 1

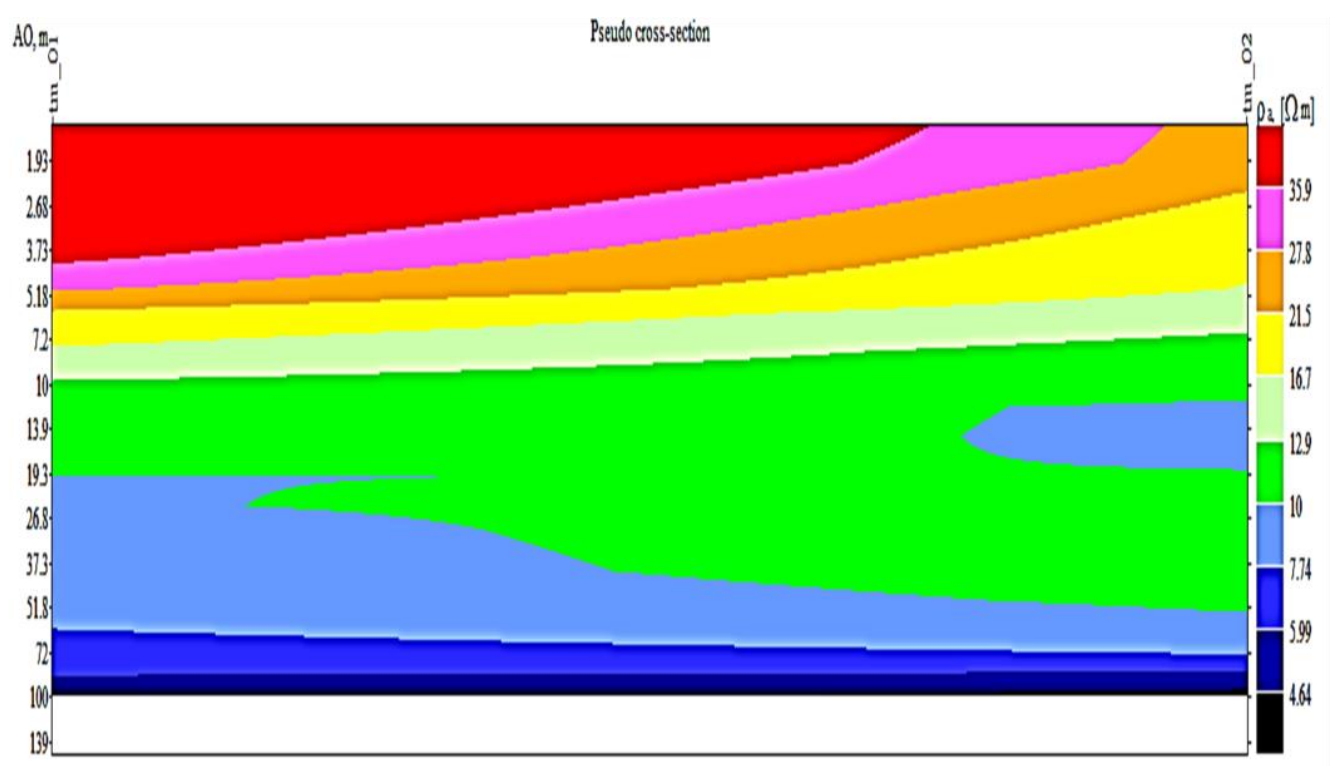

Gambar 6. Penampang resistivitas lapisan yang sebenarnya pada line 1 dan line 2

Tabel 7. Kedalaman, ketebalan, dan resistivitas lapisan sebenarnya line 1

\begin{tabular}{cccc}
\hline $\begin{array}{c}\text { Kedalaman dari titik VES, } \\
\text { altitude }(\mathrm{m})\end{array}$ & $\begin{array}{c}\text { Kedalaman dari } \\
\text { permukaan, d }(\mathrm{m})\end{array}$ & $\begin{array}{c}\text { Ketebalan, h }(\mathrm{m}) \\
\text { Resistivitas lapisan, rho } \\
(\Omega \mathrm{m})\end{array}$ \\
\hline$-0,75$ & 0,75 & 0,75 & 135 \\
$-2,34$ & 2,34 & 1,59 & 51,5 \\
$-13,24$ & 13,2 & 10,9 & 11 \\
$-22,95$ & 23 & 9,71 & 6,31 \\
$-43,85$ & 43,8 & 20,9 & 16,9 \\
$-52,49$ & 52,5 & 8,64 & 0,598 \\
& & Tak terdeteksi & 0,0521 \\
\hline
\end{tabular}


Wowor et al.: Analysis of aquifers, humidity levels with geoelectric resistivity, and NDW Index ...
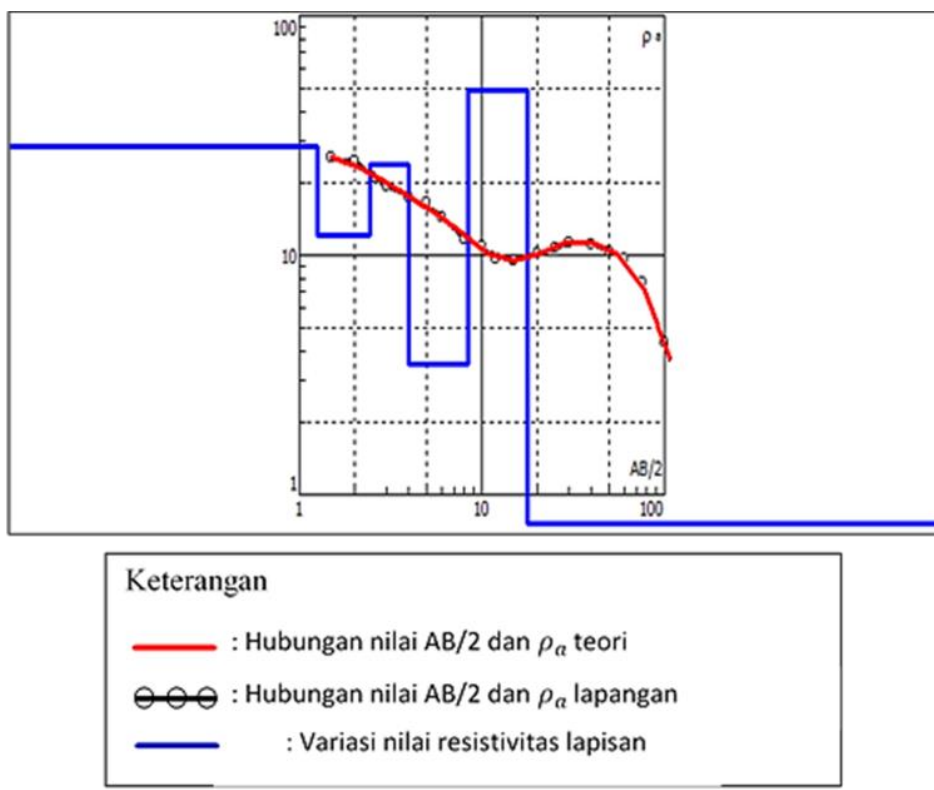

Gambar 7. Kurva hasil inversi untuk line 2

Tabel 8. Kedalaman, ketebalan, dan resistivitas lapisan sebenarnya line 2

\begin{tabular}{cccc}
\hline $\begin{array}{c}\text { Kedalaman dari titik VES, } \\
\text { altitude }(\mathrm{m})\end{array}$ & $\begin{array}{c}\text { Kedalaman dari } \\
\text { permukaan, } \mathrm{d}(\mathrm{m})\end{array}$ & Ketebalan, $\mathrm{h}(\mathrm{m})$ & $\begin{array}{c}\text { Resistivitas lapisan, rho } \\
(\Omega \mathrm{m})\end{array}$ \\
\hline$-1,26$ & 1,26 & 1,26 & 28,5 \\
$-2,42$ & 2,42 & 1,16 & 12,1 \\
$-3,98$ & 3,98 & 1,56 & 23,8 \\
$-8,41$ & 8,41 & 4,43 & 3,53 \\
$-17,89$ & 17,9 & 9,48 & 49,2 \\
$-67,99$ & 68 & 50,1 & 0,0632 \\
& & Tak terdeteksi & 0,283 \\
\hline
\end{tabular}

Hasil inversi untuk line 3 dapat dilihat pada Gambar 8, Gambar 9, dan Tabel 9. Kurva pada Gambar 8 memiliki RMSE sebesar 2,31\%. Hasil inversi untuk line 4 dapat dilihat pada Gambar 10, Gambar 9, dan Tabel 10. Kurva pada Gambar 9, memiliki RMSE sebesar 2,08\%.

Berdasarkan Gambar 9, data untuk kedalaman, ketebalan, dan resistivitas lapisan untuk line 3 dan line 4 dapat dilihat pada Tabel 9 dan 10 . Interpretasi jenis lapisan berdasarkan Tabel 9, dapat dijelaskan sebagai berikut:

- Tanah penutup: kedalaman sampai dengan 0,75 $\mathrm{m}$, mempunyai resistivitas $508 \Omega \mathrm{m}$, diinterpretasikan sebagai lapisan gamping.

- Lapisan kedua: kedalaman 0,75-5,34 m, mempunyai resistivitas 150-197 $\Omega \mathrm{m}$, diinterpretasikan sebagai andesit.

- Lapisan ketiga: kedalaman 5,34-8,8 m, mempunyai resistivitas $39,6 \Omega \mathrm{m}$, diinterpretasikan sebagai lanau, tufa vulkanik.
- Lapisan keempat: kedalaman 8,8-18,3 m, mempunyai resistivitas $255 \Omega \mathrm{m}$, diinterpretasikan sebagai batu pasir.

- Lapisan kelima: kedalaman 18,3 m sampai tak terdeteksi, mempunyai resistivitas 0,69-0,952 $\Omega \mathrm{m}$ diinterpretasikan sebagai lapisan air tanah.

Interpretasi jenis lapisan berdasarkan Tabel 10, dapat dijelaskan sebagai berikut:

- Tanah penutup: kedalaman sampai dengan 0,75 $\mathrm{m}$, mempunyai resistivitas $79,1 \Omega \mathrm{m}$, diinterpretasikan sebagai lempung.

- Lapisan kedua: kedalaman 0,75-15,8 m, mempunyai resistivitas 5,51-17,1 $\Omega \mathrm{m}$, diinterpretasikan sebagai plempung

- Lapisan ketiga: kedalaman 15,8-26,6 m, mempunyai resistivitas $0,585 \Omega \mathrm{m}$, diinterpretasikan sebagai lapisan air tanah.

- Lapisan keempat: kedalaman 26,6 m sampai tak terdeteksi, mempunyai resistivitas $109 \Omega \mathrm{m}$, diinterpretasikan sebagai pasir tufaan yang padu. 


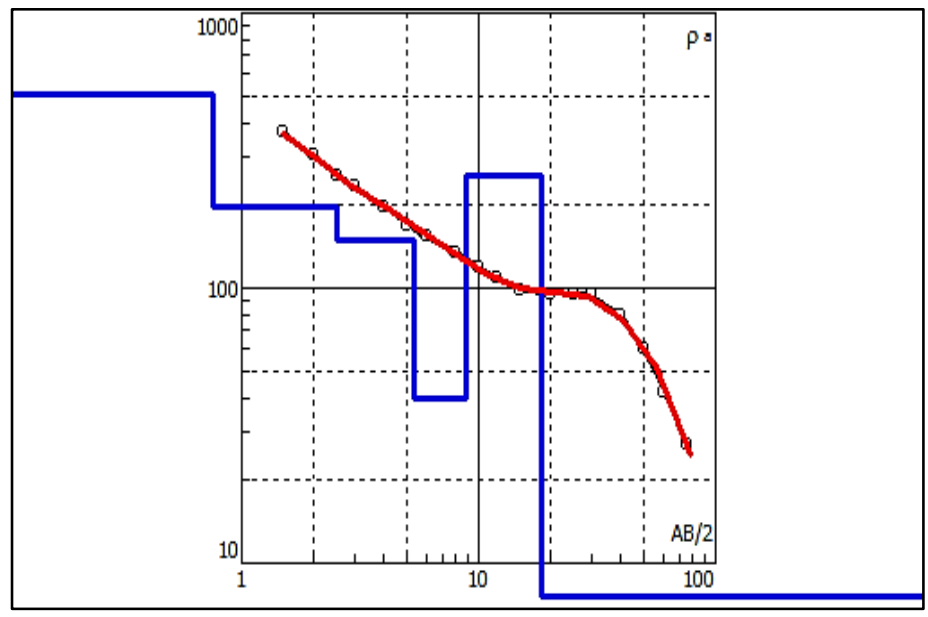

Keterangan:

: Hubungan nilai $\mathrm{AB} / 2$ dan $\rho_{a}$ teori

$\ominus \curvearrowright$ : Hubungan nilai $\mathrm{AB} / 2$ dan $\rho_{a}$ lapangan

: Variasi nilai resistivitas lapisan

Gambar 8. Kurva hasil inversi untuk line 3

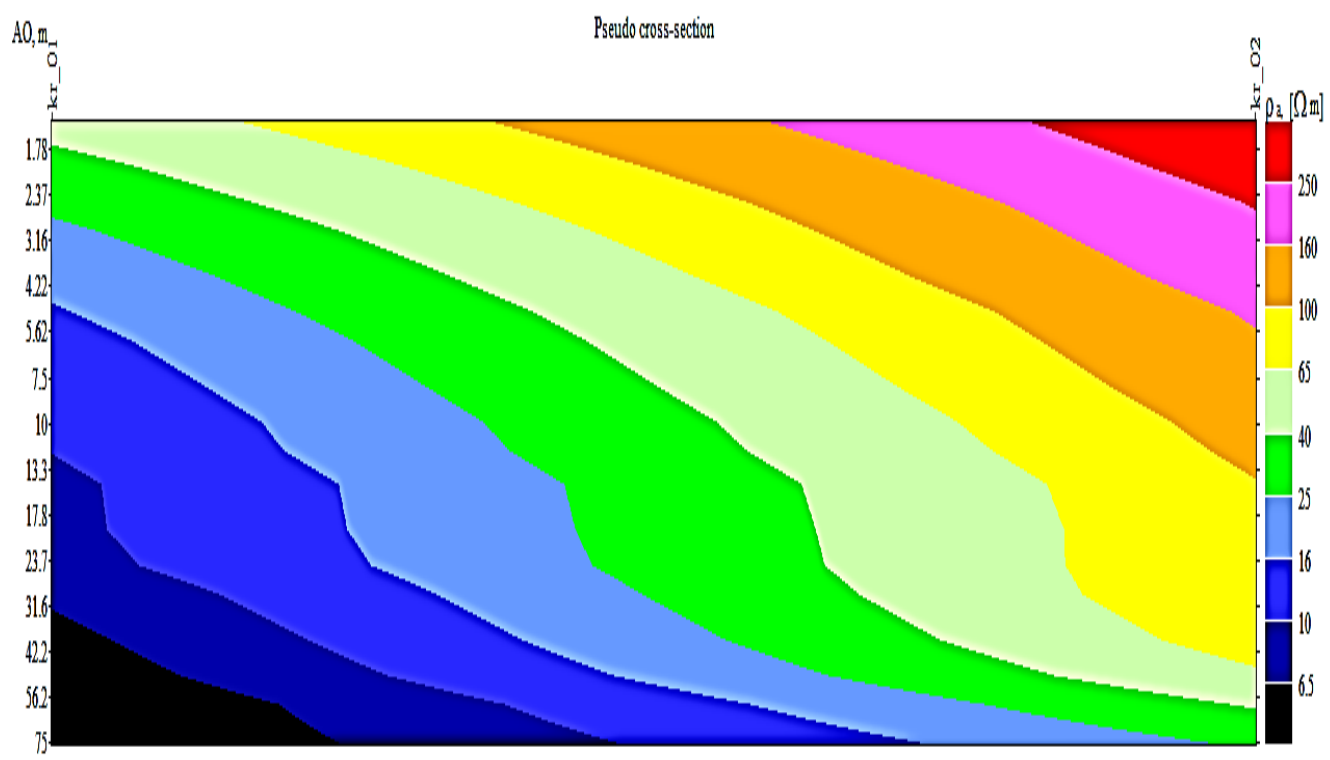

Gambar 9. Penampang resistivitas lapisan line 3 dan line 4

Tabel 9. Kedalaman, ketebalan, dan resistivitas lapisan sebenarnya line 3

\begin{tabular}{cccc}
\hline $\begin{array}{c}\text { Kedalaman dari titik VES, } \\
\text { altitude }(\mathrm{m})\end{array}$ & $\begin{array}{c}\text { Kedalaman dari } \\
\text { permukaan, } \mathrm{d}(\mathrm{m})\end{array}$ & Ketebalan, h $(\mathrm{m})$ & $\begin{array}{c}\text { Resistivitas lapisan, rho } \\
(\Omega \mathrm{m})\end{array}$ \\
\hline$-0,75$ & 0,75 & 0,75 & 508 \\
$-2,52$ & 2,52 & 1,77 & 197 \\
$-5,34$ & 5,34 & 2,82 & 150 \\
$-8,8$ & 8,8 & 3,46 & 39,6 \\
$-18,26$ & 18,3 & 9,46 & 255 \\
$-51,06$ & 51,1 & 32,8 & 0,69 \\
& & Tak terdeteksi & 0,952 \\
\hline
\end{tabular}



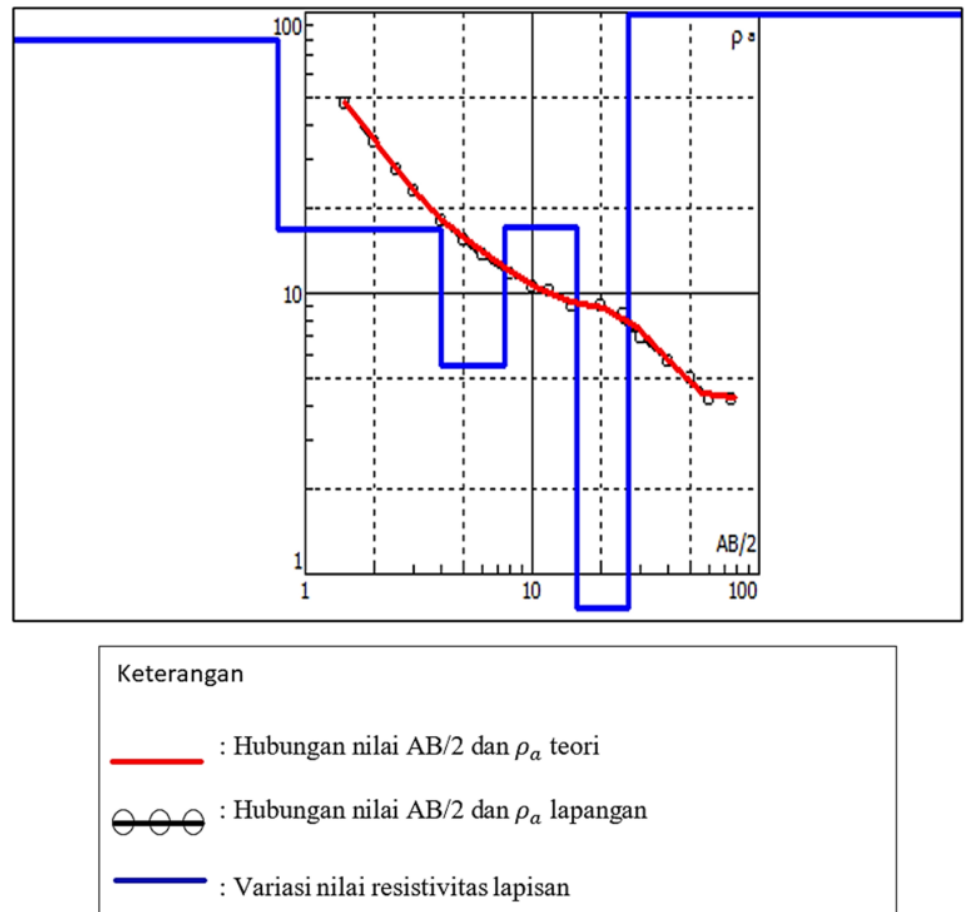

Gambar 10. Kurva hasil inversi untuk line 4

Tabel 10. Kedalaman, ketebalan, dan resistivitas lapisan sebenarnya line 4

\begin{tabular}{cccc}
\hline $\begin{array}{c}\text { Kedalaman dari titik VES, } \\
\text { altitude }(\mathrm{m})\end{array}$ & $\begin{array}{c}\text { Kedalaman dari } \\
\text { permukaan, } \mathrm{d}(\mathrm{m})\end{array}$ & Ketebalan, h $(\mathrm{m})$ & $\begin{array}{c}\text { Resistivitas lapisan, rho } \\
(\Omega \mathrm{m})\end{array}$ \\
\hline$-0,75$ & 0,75 & 0,75 & 79,1 \\
$-2,52$ & 2,52 & 1,77 & 17 \\
-4 & 4 & 1,48 & 16,9 \\
$-7,58$ & 7,58 & 3,58 & 5,51 \\
$-15,82$ & 15,8 & 8,24 & 17,1 \\
$-26,62$ & 26,6 & 10,8 & 0,585 \\
& & Tak terdeteksi & 109 \\
\hline
\end{tabular}

Setelah dianalisis sesuai dengan diagram alir analisis data pada Gambar 4, maka akuifer atau lapisan pembawa air di lokasi penelitian diinterpretasikan sebagai lapisan pasir yang mengandung sisipan tufa seperti pada lapisan pasir tufaan bersifat lepas dan pasir tufaan bersifat sedang. Lapisan ini memiliki porositas dan permeabilitas yang cukup baik untuk menyimpan dan mengalirkan fluida yang diindikasikan dengan nilai resistivitas rendah pada rentang nilai 5,5-49,2 $\Omega \mathrm{m}$. Hal ini didukung pula oleh Asmaranto (2012), Lenni (2008), dan penelitian dari Wibowo (2015), Karunianto (2013), Winarti (2013), Pryambodo (2014), dan Fauziyah et al. (2015), bahwa air berperan sebagai konduktor yang baik di mana kandungan air dalam batuan akan mempengaruhi nilai resistivitas, karena resistivitas berbanding terbalik dengan konduktivitas sesuai dengan persamaan $\rho=\frac{1}{\sigma}$ sehingga semakin besar nilai konduktivitas batuan, maka nilai resistivi-tas akan semakin kecil dan demikian pula sebaliknya.

\section{Tingkat Kelembaban}

Gambar 11 memperlihatkan manifestasi Desa Tempang Dua dan Desa Karumenga di Kecamatan Langoan Utara, berdasarkan letak administrasi. Dilakukan resample untuk membatasi wilayah kajian, khusus untuk daerah panas bumi. Citra wilayah kajian dibatasi dengan koordinat sebagai berikut: $X_{\max }=704000 ; X_{\min }=703491 ; Y_{\max }=$ 129850; $Y_{\min }=129250$. Proses resample melibatkan 2 band dalam citra satelit Landsat 8 OLI, yaitu band NIR dan band SWIR. Dari resample yang dilakukan diperoleh hasil Peta NDWI (Gambar 12). 


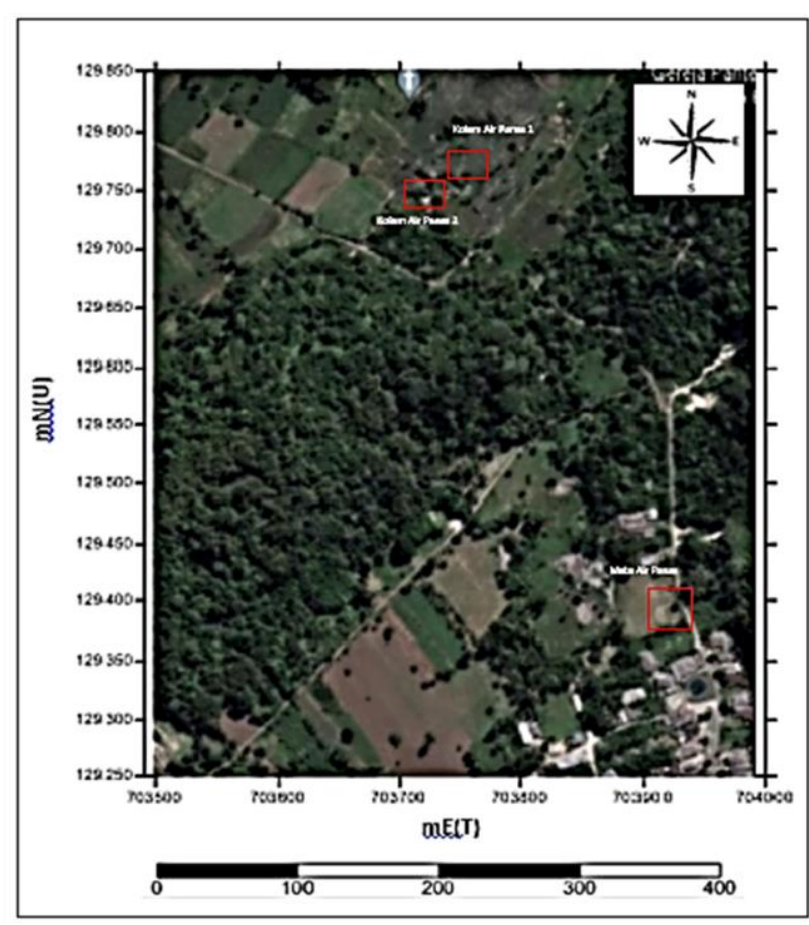

Gambar 11. Letak manifestasi di lapangan

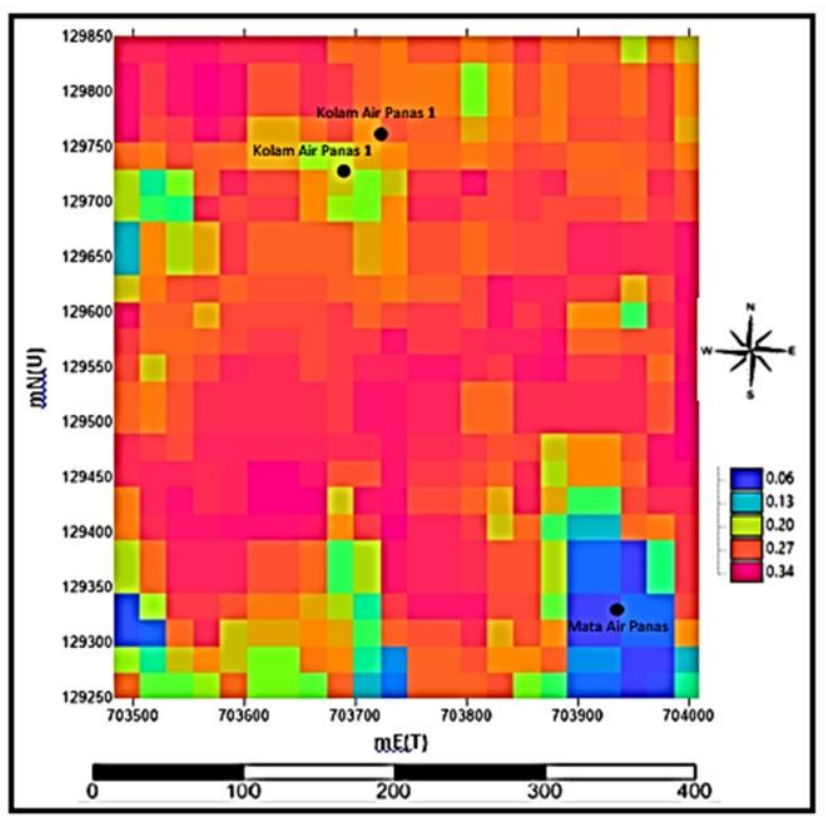

Gambar 12. Peta NDWI

Peta NDWI adalah peta yang berfungsi untuk menunjukan nilai spectral dari manifestasi yang di teliti. Manifestasi yang diteliti dibagi dalam 3 titik manifestasi. Manifetasi yang di ambil adalah manifestasi yang berdominasi air, yaitu kolam air panas dan mata air panas. Dari data citra yang telah di proses mengunakan persamaan NDWI diperoleh nilai spectral dari masing-masing manifestasi (Tabel 11).
Nilai spektral manifestasi tersebut berkiasar antara 0.01 dan 0.27. Berdasarkan tabel klasifikasi, manifestasi-manifestasi tersebut dapat di klasifikasikan tingkat kebasahannya berdasarkan nilai spektral (Tabel 12).

Klasifikasi NDWI berdasarkan Tabel 2, dapat di jelaskan Sebagai berikut:

1. Manifestasi kolam air panas 1: nilai spektral berkisar 0.23-0.27 dan termasuk dalam tingkat kebasahan sedang di mana, jika di lakukan tinjau lokasi, manifestasi tersebut terletak di area dengan kerapatan vegetasi yang cukup tinggi dengan pepohonan dan jauh dengan area pemukiman/desa.

2. Manifestasi kolam air panas 2: memiliki nilai spektal berkisar 0.20-0.21 dan dalam klasifikasi sedang. Lokasi manifestasi ini tidak jauh dengan manifestasi 1, dan lokasi ini termasuk dalam area kerapatan vegetasi yang cukup tinggi.

3. Manifestasi mata air panas: nilai spekral berkisar 0.01-0.10. Manifestasi ini terletak di wilayah pemukiman desa sehinga, jika di bandingkan dengan kolam air panas 1 dan 2, nilainya lebih rendah karena vegetasi di sekitar manifestasi ini tergolong kurang dan di manfaatkan oleh masyarakat sebagai pemandian air panas.

Berdasarkan teori, kolam dan mata air panas memiliki kandungan air/tingkat kebasahan/ kelembaban yang tinggi. Hal ini didukung pula dari pengamatan langsung di lapangan di mana daerah sekitar manifestasi memiliki kerapatan vegetasi yang tinggi. Hal ini didukung oleh penelitian yang di lakukan Haikal and Risdiyanto (2014), yang menyatakan, bahwa semakin rendah vegetasi pada lahan tersebut maka tingkat ekstrim kebasahan di lahan tersebut semakin tinggi sedangkan jika vegetasinya banyak dan rapat maka indeks kebasahan tersebut tinggi.

\section{Hubungan Kondisi Akuifer dan Tingkat Kelembaban terhadap Kelangsungan Sistem Panas Bumi}

Berdasarkan litologinya, air tanah yang terdapat pada lokasi penelitian diinterpretasikan sebagai air tanah atau akuifer semi tertekan (semi confined aquifer) dan akuifer bebas (unconfined aquifer). Pada akuifer semi tertekan (semi confined aquifer), akuifer terletak antara lapisan akuitard dan lapisan akuiklud (Kodoatie, 1976 cited in Ratnawati, 2009).

Lapisan akuitard adalah lapisan yang berada di atas akuifer, yang bersifat lambat air, yaitu dapat meluluskan air secara vertikal tapi tidak secara horizontal (Irjan, 2012). Lapisan akuitard pada lokasi 
Wowor et al.: Analysis of aquifers, humidity levels with geoelectric resistivity, and NDW Index ...

Tabel 11. Hasil nilai spektral NDWI

\begin{tabular}{cccc}
\hline \multirow{2}{*}{ Jenis Manifestasi } & \multicolumn{2}{c}{ Koordinat } & Nilai \\
& $\mathrm{X}$ & $\mathrm{Y}$ & $\begin{array}{c}\text { Spektral } \\
\text { NDWI }\end{array}$ \\
\hline Kolam Air Panas 1 & 703718 & 129760 & $0.23-0.27$ \\
Kolam Air Panas 2 & 703688 & 129729 & $0.20-0.21$ \\
Mata Air Panas & 703934 & 129331 & $0.01-0.10$ \\
\hline
\end{tabular}

Tabel 12. Hasil klasifikasi NDWI berdasarkan nilai spektral

\begin{tabular}{ccc}
\hline Jenis Manifestasi & $\begin{array}{c}\text { Nilai } \\
\text { Spektral }\end{array}$ & $\begin{array}{c}\text { Tingkat } \\
\text { Kebasahan }\end{array}$ \\
\hline Kolam Air Panas 1 & $0.23-0.27$ & $\begin{array}{c}\text { Kebasahan } \\
\text { Sedang }\end{array}$ \\
Kolam Air Panas 2 & $0.20-0.21$ & $\begin{array}{c}\text { Kebasahan } \\
\text { Sedang } \\
\text { Kebasahan } \\
\text { Sedang }\end{array}$ \\
\hline
\end{tabular}

penelitian diinterpretasikan sebagai lapisan penutup yang sebagian besar terdiri dari tufa Tondano dan diindikasikan oleh nilai resistivitas yang tinggi (51,5 - $508 \Omega \mathrm{m}$ ).

Lapisan yang berada di bawah akuifer adalah akuiklud, yaitu lapisan batuan kedap air (Hirnawan, 2003). Lapisan akuiklud diinterpretasikan sebagai lempung. Lapisan ini memiliki nilai resitivitas sangat rendah $(0,05-3,5 \Omega \mathrm{m})$. Lapisan lempung pada lokasi penelitian diduga sebagai lapisan batuan penudung (cap rock) pada reservoir panas bumi di mana rekahan yang ada dibawah permukaan memungkinkan fluida panas bumi dari reservoir naik ke permukaan dan menyebabkan batuan yang dilaluinya berubah menjadi lempung hidrotermal. Kehadiran ion - ion berupa $\mathrm{HCO}_{3}{ }^{-}, \mathrm{SO}_{4}{ }^{2-}, \mathrm{Cl}^{-}$, dan lain-lain pada fluida panas bumi juga dapat meningkatkan harga konduktivitas batuan sehingga resistivitas yang terukur lebih rendah dibandingkan pada daerah yang tidak berasosiasi dengan sistem panas bumi.

Pada akuifer bebas (unconfined aquifer), akuifer tidak mempunyai pembatas di lapisan atasnya dan memiliki lapisan akuiklud di lapisan bawahnya, sehingga akuifer ini tergolong ke dalam air tanah permukaan atau freatik (Irawan and Puradimaja, 2012). Keberadaan akuifer ini diduga disebabkan oleh adanya keluaran manifestasi panas bumi berupa kolam air panas disekitar bentangan untuk pengukuran VES.

Berdasarkan analisis data yang dilakukan, maka produktifitas akuifer pada lokasi penelitian diinterpretasikan tergolong kedalam akuifer produktif sedang dengan penyebaran luas dan muka air tanah bebas beragam, yaitu lebih dari $5 \mathrm{~m}$ di bawah muka tanah dan muka air tanah yang berada di atas permukaan yang dicirikan dengan adanya manifestasi panas bumi (discharge area). Begitu juga dengan analisis NDWI di mana hasil yang diperoleh tingkat kelembaban dengan klasifikasi nilai spektral manifestasi berkisar 0.01-0.27 dan termasuk dalam kualifikasi kebahasahan sedang, sesuai dengan kondisi lapangan di mana manifestasi tersebut berada di area perkebunan dan pemukiman/desa dengan kerapatan vegetasi yang cukup tinggi.

Potensi panas bumi suatu daerah sangat didukung oleh ketersediaan air tanah di daerah tersebut (Listyani and Budiadi, 2013). Kondisi akuifer produktif sedang yang terdapat di Desa Tempang Dua dan Desa Karumenga memiliki peranan penting bagi produktivitas reservoir hidrotermal. Jika keadaan ini tetap dijaga dengan baik, maka kelangsungan sistem panas bumi area Tompaso akan dapat bertahan untuk jangka waktu yang panjang.

\section{KESIMPULAN}

Akuifer di Desa Tempang Dua terletak di dua lokasi, yaitu pada lapisan kedalaman sekitar $6 \mathrm{~m}$ di bawah permukaan dengan ketebalan sekitar $12 \mathrm{~m}$; dan pada lapisan kedalaman 0-3,98 m di bawah permukaan dengan ketebalan sekitar 3,98 m. Akuifer di Desa Karumenga terletak pada lapisan kedalaman sekitar 5-16 $\mathrm{m}$ di bawah permukaan dengan ketebalan sekitar $11 \mathrm{~m}$. Nilai spektral pada daerah sekitar manifestasi panas bumi dominasi air di Kecamatan Langowan Utara, khususnya yang ada di Desa Tempang Dua dan Desa Karumenga, berkisar 0.010.27 dan termasuk dalam tingkat kebasahan sedang. Selain itu, Desa Tempang Dua dan Desa Karumenga memiliki Kondisi akuifer produktif sedang dan klasifikasi tingkat kelembaban termasuk dalam kebasahan sedang. Hal ini menunjukan hubungan yang baik dalam mendukung kelangsungan sistem panas bumi wilayah Tompaso.

Ucapan terima kasih. Penulis mengucapkan terima kasih kepada semua pihak yang telah membantu dalam pelaksanaan penelitian dan penulisan naskah hasil penelitian untuk publikasi dalam jurnal ilmiah. "Kami menyatakan bahwa tidak ada konflik kepentingan dengan organisasi manapun mengenai bahan yang didiskusikan dalam naskah ini”.

\section{REFERENSI}

ASMARANTO, R. (2012) Identifikasi Air Tanah menggunakan Metode Resistivity. Bahan Ajar 
Hidrogeologi. Malang: Jurusan Teknik Pengairan, Fakultas Teknik, Universitas Brawijaya.

FAUZIYAH, S., KHUMAEDI and LINUWIH, S. (2015) Interpretasi struktur bawah permukaan daerah mata air panas Krakal Kebumen dengan metode geolistrik. Jurnal MIPA, 38 (2), pp. 138143.

GAO, B.-C. (1996) NDWI - a normalized difference water index for remote sensing of vegetation liquid water from space. Remote Sensing of Environtment, 58 (3), pp. 257-266.

HANDOKO, B.T. (2010) Resource Assessment of Tompaso Geothermal Field, Indonesia. Report 2010, Number 30. Iceland: United Nations University Geothermal Training Programme.

HAIKAL, T. and RISDIYANTO, I. (2014) Analisis Normalized Difference Wetness Index (NDWI) dengan menggunakan Data Citra Landsat 5 TM (Studi Kasus: Provinsi Jambi Path/Row:125/61). Undergraduate Theses. Bogor: Institut Pertanian Bogor.

HIRNAWAN, F. (2003) Hidrogeologi Air Tanah. Bandung: Universitas Padjadjaran.

IRAWAN, D. AND PURADIMAJA, D. (2012) Hidrogeologi Umum. Bandung: Fakultas Ilmu dan Teknologi Kebumian, ITB.

IRJAN (2012) Pemetaan potensi air-tanah (Aquifer) berdasarkan interpretasi data resistivitas Wenner Sounding (studi kasus: pengembangan Kampus II Universitas Negeri Maulana Malik Ibsrahim Malang di Desa Tlekung Kecamatan Junrejo Kota Batu). Jurnal Neutrino, 4 (2), pp. 201-212.

KARUNIANTO, A.J. (2013) Analisis kedalaman potensi akuifer air tanah dengan pemodelan distribusi tahanan jenis secara inversi 2-D Desa Kompas Raya, Nanga Pinoh, Melawi, Kalimantan Barat. Eksplorium, 34 (1), pp. 11-22.
LENNI (2008) Medan Elektromagnetik. Bahan Ajar: konduktor Arus, Hukum Ohm dan Efek Bayangan. Pusat Pengembangan Bahan Ajar. Jakarta: Universitas Mercu Buana.

LISTYANI, T.R.A. and BUDIADI, Ev. (2013) Tinjauan Hidrogeologi Sebagai Pendukung Potensi Panas Bumi Daerah Gedongsongo, Jawa Tengah. Jurnal Teknologi, 6 (1): pp. 65-72.

PRYAMBODO, D.G., KUSUMAH, G. and SUDIRMAN, N. (2014) Pendugaan Akuifer Airtanah di pesisir Pulau Solor, Nusa Tenggara Timur. Jurnal Segara, 10 (2), pp. 147-155.

RATNAWATI, S.U. (2009) Pendugaan Kedudukan Akuifer dengan Aplikasi Geolistrik Metode Tahanan Jenis Konfigurasi Schlumberger (Studi Kasus Desa Banioro dan Sekitarnya, Kecamatan Karangsambung, Kabupaten Kebumen Jawa Tengah). skripsi. Semarang: Jurusan Fisika Fakultas Matematika dan Ilmu Pengetahuan Alam, Universitas Negeri Semarang.

SARDIYANTO (2010) Sistem Panas bumi Lapangan Tompaso Minahasa, Sulawesi Utara Tugas akhir B. Bandung: Program Studi Teknik Geologi, Fakultas Ilmu dan Teknologi Kebumian, Institut Teknologi Bandung.

TILLERY, B.W., ENGER, E.D. and ROSS, F.C. (2007) Integrated Science. Third Edition. New York: McGraw-Hill. 2007.

WIBOWO, N.B. (2015) Spatial analysis of surface aquifer thickness based frequency predominant in Bantul District. Indonesian Journal of Applied Physics, 5 (1), pp. 62-70.

WINARTI (2013) Metode geolistrik untuk mendeteksi akuifer airtanah di daerah sulit air (studi kasus di Kecamatan Takeran, Poncol dan Parang, Kabupaten Magetan). Angkasa, V (1), pp. 83-94. 